\title{
Nutritional value, bioactive components and antioxidant activity of Schisandra chinensis (Turcz.) Baill. leaves
}

\author{
Mykhailo Zhurba ${ }^{1}$, Olga Shelepova ${ }^{2}$, Natalia Hudz $^{3}$, Eva Ivanišová ${ }^{4}$, Anna Adriana Bieniek ${ }^{5}$, \\ Agata Antoniewska-Krzeska ${ }^{6}$, Katarína Fatrcová-Šramková ${ }^{4}$
${ }^{1}$ M.M. Gryshko National Botanical Garden of the National Academy of Sciences of Ukraine, Kyiv, Ukraine
${ }^{2}$ N.V. Tsitsin Main Botanical Garden of Russian Academy of Sciences, Moscow, Russia
${ }^{3}$ Danylo Halytsky Lviv National Medical University, Lviv, Ukraine
${ }^{4}$ Slovak University of Agriculture in Nitra, Slovak Republic
${ }^{5}$ University of Warmia and Mazury in Olsztyn, Poland
${ }^{6}$ Institute of Human Nutrition Sciences, Faculty of Human Nutrition, Warsaw University of Life Sciences
(WULS-SGGW), Warsaw, Poland

\section{ORCID}

Mykhailo Zhurba: https://orcid.org/0000-0001-5318-3961

Olga Shelepova: https://orcid.org/0000-0003-2011-6054

Natalia Hudz: https://orcid.org/0000-0002-2240-0852

Eva Ivanišová: https://orcid.org/0000-0001-5193-2957

Anna Adriana Bieniek: https://orcid.org/0000-0002-5903-1405

Agata Antoniewska-Krzeska: https://orcid.org/0000-0002-4293-5811

Katarína Fatrcová-Šramková: https://orcid.org/0000-0002-8696-4796

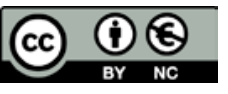

Article Details:

Received: 2021-06-28

Accepted: 2021-07-28

Available online: 2021-11-30

DOI: https://doi.org/10.15414/ainhlq.2021.0020

\begin{abstract}
As a part of the ongoing interest in the nutritional and antioxidative properties of a little-known East Asian plant species, the aim of the study was to determine the contents of macronutrients and selected elements, profiles of fatty and amino acids, the content of phenolic compounds, $\beta$-carotene, vitamin A and E, and antioxidant activity of Schisandra chinensis (Turcz.) Baill. edible leaves. Schisandra chinensis leaves contained a small amount of lipids $4.36 \%$ and $12.38 \%$ of proteins. Sugars (fructose, maltose, sucrose, and lactose) were detected only in trace amounts $(<0.5 \mathrm{~g} / \mathrm{kg})$. The $\beta$-carotene content was $17.70 \mathrm{mg} / \mathrm{kg}$. The fatty acid profile of leaves was represented by palmitic C16:0 (44.6 g/100 g of oil), linoleic C18:2 9c12c (17.9 g/100 g of oil), and $\alpha$-linolenic C18:3 (9c12c15c 10.6 g/100 g of oil) acids. Nine out of 18 amino acids detected in leaves were essential amino acids (68.80 g/kg of dry matter leaves). Glutamic acid was found to be the major component of non-essential amino acids ( $25 \mathrm{~g} / \mathrm{kg}$ of dry matter), followed by aspartic acid (16.2 g/kg of dry matter) and leucine (14.2 g/kg of dry matter). The element composition of leaves demonstrated the presence of: macroelements ( $\mathrm{K}, \mathrm{P}, \mathrm{S}, \mathrm{Ca}, \mathrm{Mg}, \mathrm{Na}$ ), microelements ( $\mathrm{Zn}, \mathrm{Fe}, \mathrm{Cu}, \mathrm{Mn}, \mathrm{Cr}, \mathrm{Se}$ ), and metals ( $\mathrm{Al}, \mathrm{As}, \mathrm{Cd}, \mathrm{Ni}, \mathrm{Hg}, \mathrm{Pb})$. Potassium was the most abundant element in Schisandra chinensis leaves $(10209 \mathrm{mg} / \mathrm{kg}$ of dry matter of leaves), followed by $\mathrm{Ca}, \mathrm{P}$, and $\mathrm{Mg}$. The spectrophotometric assays enabled detecting phenolic compounds from three categories: polyphenols (44.32 mg galic acid equivalents/g of dry matter of leaves), total flavonoids (29.16 mg quercetin equivalents/g of dry matter of leaves) and phenolic acids (6.12 mg caffeic acid equivalents/g of dry matter of leaves) in Schisandra chinensis leaves. The antioxidant activity of $S$. chinensis leaves, as determined
\end{abstract}

\footnotetext{
*Corresponding Author: Katarína Fatrcová-Šramková, Slovak University of Agriculture in Nitra, Faculty of Agrobiology and Food Resources, Institute of Nutrition and Genomics, Tr. A. Hlinku 2, 949 76, Nitra, Slovakia $\triangle$ katarina.sramkova@uniag.sk
} 
by DPPH•, was at the level of $9.19 \mathrm{mg}$ TEAC/g of dry matter of leaves, and $214 \mathrm{mg}$ TEAC/g of dry matter of leaves (as determind by molybdenum reducing antioxidant power). The composition of Schisandra chinensis leaves suggest it to become an inexpensive novel plant source of functional foods, supplements, and as new ingredient in human diet.

Keywords: Schisandra chinensis, leaves, chemical composition

\section{Introduction}

Ample studies have shown that non-traditional, little-known, and underutilized edible leaves of plant species, also offer some nutritional value; being a good source of macroelements, minerals, polyphenols, with impressive antioxidant activity, thus gained interest as potential functional foods (Monka et al., 2014; Ivanišová et al., 2017a; Horčinová Sedláčková et al., 2018, 2019; Klymenko et al., 2017, 2019; Vinogradova et al., 2020; Grygorieva et al., 2017, 2018a, 2018b, 2018c, 2020a, $2020 \mathrm{~b}$ ). However, to the best of authors' knowledge, the data about nutrient composition and therapeutic properties of different morphological parts of plants is highly limited.

Schisandra chinensis (Turcz.) Baill. fruits proved to be a rich source of carbohydrates, vitamins, phytosterols, organic acids (Hancke et al., 1999; Wu et al., 2011; Tong et al., 2012; Ekiert et al., 2013; Szopa and Ekiert, 2014). The main bioactive components determined in fruits are lignans ("schisandra lignans"), which are also present in Schisandra chinensis leaves, but in lower amounts (Ekiert et al., 2013). Study of Schisandra chinensis leaves performed by Xia et al. (2015) allowed detection of 16,17-Seco-pre-schisanartanes $\left(\mathrm{C}_{29}\right)$, known as new triterpenoid from plant species of the family Schisandraceae. Schisandra chinensis leaves are known to be used in infusions or as spices (Ciorchină et al., 2011). The essential oil of $S$. chinensis also possess valuable properties (Merdzhanov et al., 2016).

The health beneficial properties of Schisandra chinensis fruits primarily refer to Traditional Chinese Medicine. Previous studies showed that Schisandra chinensis fruits possess hepatoprotective (Panossian and Wikman, 2008), anti-inflammatory (Hu et al., 2014), anticancer (Hwang et al., 2011) immunostimulant (Chen et al., 2012a; Zhao et al., 2013), anti-obesity (Park et al., 2012), antiviral (Xu et al., 2015), antibacterial (Chen et al., 2011; Hakala et al., 2015; Tvrdá et al., 2020), adaptogenic, ergogenic activity (Jeong et al., 2013; Sa et al., 2015), antioxidant and detoxifying properties (Chiu et al., 2008; Yim et al., 2009; Thandavarayan et al., 2015; Wang et al., 2018). Moreover, S. chinensis fruits extracts are used in cosmetic industry (Quirin, 2008; Dweck and Marshall, 2009; Chiu et al., 2011).

Despite the well-studied composition and properties of the fruits of Schisandra chinensis, the nutritional value and bioactive components of leaves remains to be studied. Thus, the aim of this study was to determine the contents of macronutrients and selected elements, profiles of fatty and amino acids, the content of phenolic compounds, $\beta$-carotene, vitamin $A$ and $E$, and antioxidantive activity of Schisandra chinensis edible leaves.

\section{Material and methodology}

\section{Sampling}

The Schisandra chinensis leaves (Figure 1) were collected in July 2020 from the trees growing in the Botanical Garden (Slovak University of Agriculture in Nitra).

\section{Chemicals and reagnets}

All the chemicals and reagnets used were of analytical grade and were purchased from Sigma-Aldrich (Steinheim, Germany), Merck (Darmstadt, Germany), and CentralChem (Slovakia).

\section{Analysis of proximate composition}

Dry matter, ash, and protein contents were determined according to CSN-EN 12145 procedures (1997). Total lipid content was determined according to ISO method (ISO 659, 1998).

\section{Analysis of sugars}

For the determination of sugars content, $1 \mathrm{~g}$ of leaves was vigorously shaken with $10 \mathrm{~mL}$ of water/ ethanol mixture $(4: 1)$ on a vertical shake table (GFL, Germany). After $1 \mathrm{~h}$ of the extraction, the mixture was centrifuged at $6000 \mathrm{rpm}$ for $4 \mathrm{~min}$ (EBA 21, Hettich, Germany). The supernatant was filtered through filter paper with $0.45 \mathrm{~mm}$ pore size (Labicom, Czech Republic) and filled up to $50 \mathrm{~mL}$ in a volumetric flask with ultrapure water.

An HPLC analysis of sugars (fructose, maltose, sucrose, lactose) was performed using an Agilent Infinity 1260 instrument (Agilent Technologies, USA) equipped with an ELSD detector. Separation of sugars was conducted on a Prevail Carbohydrates ES column $(250 \times 4.6 \mathrm{~mm})$. Acetonitrile/water $(75: 25 \mathrm{v} / \mathrm{v})$ was used as the mobile phase. The identification of sugars was made by comparison the relative retention times of sample 


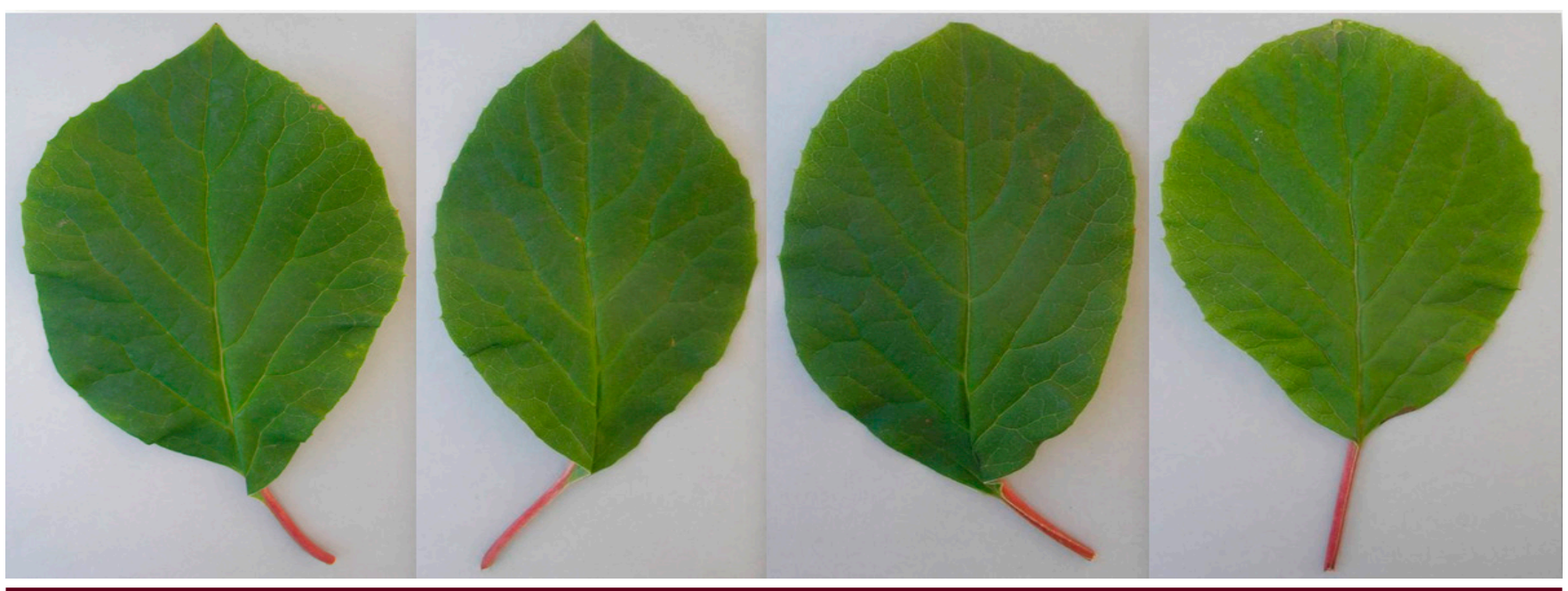

Figure 1 Leaves of Schisandra chinensis (Turcz.) Baill.

peaks with standards Sigma-Aldrich (Steinheim, Germany). The contents of sugars were expressed as $\mathrm{g} / \mathrm{kg}$ of dry leaves.

\section{Beta-carotene carotenoids content}

Beta-carotene content was extracted following the method of Sarker and Oba (2019). 1 g of dry leaf sample was ground thoroughly in a mortar and pestle with $10 \mathrm{~mL}$ of $80 \%$ acetone. After removing the supernatant in a volumetric flask, the extract was centrifuged at $10000 \times \mathrm{g}$ for 3-4 min. The final volume was brought up to $20 \mathrm{~mL}$. The absorbance was taken at $510 \mathrm{~nm}$ and $480 \mathrm{~nm}$ using a spectrophotometer (UV-VIS spectrophotometer, Jenway Model 6405, England). Data were expressed as mg beta-carotene per kg of dry leaves. The following formula was used to measure the beta-carotene content:

Beta-carotene $=7.6($ Abs. at 480) $-1.49($ Abs. at 510) $\times$ final volume $/ 1000$

\section{Elemental analysis}

The contents of macroelements, microelements and trace metals were determined by the inductively coupled plasma optical emission spectroscopy (ICPOES) according to Divis et al. (2015) by using an ICPOES instrument (Ultima 2, Horiba Scientific, France). Leaves were prepared for analysis after microwave digestion (Milestone 1200, Milestone, Italy), $0.25 \mathrm{~g}$ of sample was decomposed in a mixture of nitric acid (6 mL) (Analytika Praha Ltd, Czech Republic) and hydrochloric acid (2 mL) (Analytika Praha Ltd, Czech Republic). After the decomposition sample was filtered through filter paper $(0.45 \mathrm{~mm}$ pore size $)$ and filled up to $25 \mathrm{~mL}$ in a volumetric flask with pure water.

\section{Determination of amino acids}

Amino acid profile was determined by ion-exchange chromatography using an AAA-400 Amino Acid Analyzer (Ingos, Czech Republic) and post-column derivatization with ninhydrin and a VIS detector. Separation was provided on a glass column (length $350 \mathrm{~mm}$, inner diameter $3.7 \mathrm{~mm}$ ) filled with a strong cation exchanger in the LG ANB sodium cycle (Laboratory of Spolchemie) with average particles size of $12 \mu \mathrm{M}$ and $8 \%$ porosity. The column was heated within the range of $35-95{ }^{\circ} \mathrm{C}$, with the elution of amino acids at $74{ }^{\circ} \mathrm{C}$. A double-channel VIS detector with the inner cell volume of $5 \mu \mathrm{L}$ was set to 440 and $570 \mathrm{~nm}$. A solution of ninhydrin was prepared in $75 \%$ $\mathrm{v} / \mathrm{v}$ methyl cellosolve and in $2 \% \mathrm{v} / \mathrm{v} 4 \mathrm{M}$ acetic buffer (pH 5.5). $\mathrm{SnCl}_{2}$ was used as a reducing agent. Solution of ninhydrin was stored in an inert atmosphere $\left(\mathrm{N}_{2}\right)$ without access of light at $4{ }^{\circ} \mathrm{C}$. The flow rate was $0.25 \mathrm{~mL} / \mathrm{min}$, and the reactor temperature was $120^{\circ} \mathrm{C}$. Individual amino acids values were expressed as $\mathrm{g} / \mathrm{kg}$ of dry leaves.

\section{Fatty acid composition}

Fatty acid (FA) composition of extracted fat from Schisandra chinensis leaves was determined as follows: the samples were prepared according to official methods Ce 2-66 (1997) to convert the oils into fatty acid methyl esters (FAME). The FAME profile was analyzed by gas chromatography (GC-6890-N, Agilent Technologies, Santa Clara, USA) equipped with capillary column DB-23 (60 m ×0.25 mm, film thickness $0.25 \mu \mathrm{m}$, Agilent Technologies, Santa Clara, CA, USA) and FID detector $\left(250{ }^{\circ} \mathrm{C}\right.$; constant flow, hydrogen $40 \mathrm{~mL} /$ min, air $450 \mathrm{~mL} / \mathrm{min}$.). A detailed description of the 
chromatography conditions is presented in the work Szabóová et al. (2020). Standards of a C4-C24 FAME mixture (Supelco, Bellefonte, PA, USA) were applied in order to identify FAME peaks. The evaluation was carried out by the ChemStation 10.1 software.

\section{Spectrophotometric assays of phenolic compounds}

\section{Total phenolics content (TPC)}

The TPC was determined spectrophotometrically at $700 \mathrm{~nm}$ (UV-VIS spectrophotometer, Jenway Model 6405, England) according to Singleton and Rossi (1965) using Folin-Ciocalteu's reagent. Briefly, $0.1 \mathrm{~mL}$ of leaves ethanolic extract was diluted with $8.8 \mathrm{~mL}$ of distilled water, mixed with $0.1 \mathrm{~mL}$ of the Folin-Ciocalteu's reagent and $1 \mathrm{~mL}$ of $20 \%$ sodium carbonate. The mixture was kept in darkness for $30 \mathrm{~min}$ before measurement of absorbance. Gallic acid $\left(25-300 \mathrm{mg} / \mathrm{L} ; \mathrm{R}^{2}=0.998\right)$ was used as the standard. The results were expressed as gallic acid equivalents (GAE; mg GAE/g of dry matter of leaves).

\section{Total flavonoids content (TFC)}

The TFC was determined spectrophotometrically at $415 \mathrm{~nm}$ (UV-VIS spectrophotometer, Jenway Model 6405, England) according to a modified method of Shafii et al. (2017). An aliquot of $0.5 \mathrm{~mL}$ of leaves ethanolic extract was mixed with $0.1 \mathrm{~mL}$ of $10 \%$ ethanolic solution of aluminum chloride, $0.1 \mathrm{~mL}$ of 1 $\mathrm{M}$ potassium acetate and $4.3 \mathrm{~mL}$ of distilled water. The mixture was kept in darkness for $30 \mathrm{~min}$ before measurement of absorbance. Quercetin (1-400 mg/L; $\mathrm{R}^{2}=0.9977$ ) was used as the standard. The results were expressed as mg quercetin equivalents (QE)/g of dry matter of leaves.

\section{Phenolic acid content (TPA)}

The TPA was determined spectrophotometrically at $490 \mathrm{~nm}$ (UV-VIS spectrophotometer, Jenway Model 6405, England) according to a method described in Farmakopea Polska (1999). A $0.5 \mathrm{~mL}$ of sample extract was mixed with $0.5 \mathrm{~mL}$ of $0.5 \mathrm{M}$ hydrochloric acid, 0.5 $\mathrm{mL}$ Arnova reagent (10\% $\left.\mathrm{NaNO}_{2}+10 \% \mathrm{Na} 2 \mathrm{MoO} 4\right)$, $0.5 \mathrm{~mL}$ of $1 \mathrm{M}$ sodium hydroxide $(\mathrm{w} / \mathrm{v})$ and $0.5 \mathrm{~mL}$ of distilled water. Caffeic acid $\left(1-200 \mathrm{mg} / \mathrm{L}, \mathrm{R}^{2}=0.999\right)$ was used as a standard. The results were expressed as mg caffeic acid equivalents (CAE)/g of dry matter of leaves.

\section{Determination of antioxidant activity \\ DPPH• radical scavenging activity}

The free radical scavenging activity of leaves extract on DPPH• (2,2-diphenyl-1-picrylhydrazyl) was determined according to Sánches-Moreno et al. (1998). Briefly, $0.4 \mathrm{~mL}$ of the extract was mixed with $3.6 \mathrm{~mL}$ of DPPH• solution $(0.025 \mathrm{~g}$ of DPPH• in 100 $\mathrm{mL}$ of methanol). The absorbance was measured at $515 \mathrm{~nm}$ using a UV-Vis spectrophotometer (Jenway Model 6405, England). Trolox (6-hydroxy-2,5,7,8tetramethylchroman-2-carboxylic acid) $\quad(10-100$ $\mathrm{mg} / \mathrm{L} ; \mathrm{R}^{2}=0.989$ ) was used as standard. The results were expressed as $\mathrm{mg}$ of Trolox equivalents (TEAC)/g of dry matter of leaves.

\section{Molybdenum reducing antioxidant power (MRAP)}

The MRAP of leaves extract was determined according to the method of Prieto et al. (1999) with slight modifications. The mixture of $1 \mathrm{~mL}$ of extract, monopotassium phosphate $(2.8 \mathrm{~mL}, 0.1 \mathrm{M})$, sulfuric acid $(6 \mathrm{~mL}, 1 \mathrm{M})$, ammonium heptamolybdate $(0.4 \mathrm{~mL}$, $0.1 \mathrm{M})$ and distilled water $(0.8 \mathrm{~mL})$ was incubated at $90{ }^{\circ} \mathrm{C}$ for $120 \mathrm{~min}$, then rapidly cooled. The absorbance was measured at $700 \mathrm{~nm}$ using a UV-Vis spectrophotometer (Jenway Model 6405, England). Trolox $\left(10-1000 \mathrm{mg} / \mathrm{L} ; \mathrm{R}^{2}=0.998\right)$ was used as the standard. The results were expressed as mg of Trolox equivalents (TEAC)/g of dry matter of leaves.

\section{Statistic analysis}

The results were subjected to one-way ANOVA followed by Tukey-Kramer test, when the differences between mean values were considered significant at $p$ $<0.05$. The variability of all parameters was evaluated by descriptive statistics. The results were presented as means with standard error (SE). The PAST 2.17 software was used.

\section{Results and discussion}

The protein content of Schisandra chinensis leaves $(12.38 \%)$ was higher than in many cultivated fruits, up to $1 \%$. Our results are in agreement with other studies; in generally, leaves are a poor lipid source. Schisandra chinensis leaves contained a small amount of lipids $4.36 \%$. Sugars (fructose, maltose, sucrose, and lactose) were detected only in trace amounts $(<0.5 \mathrm{~g} / \mathrm{kg})$ (Table 1). Monosaccharides are involved in almost all major plant metabolic processes such as synthesis of organic acids, amino acids, polyphenols, pigments, and aromatic compounds (Halford et al., 2011). It has been 
observed that leaves accumulate monosaccharides in plants grown under stress conditions (Wind et al., 2010). Probably, lower levels of these macronutrients in leaves indicate optimal environmental conditions for plant growth.

Table 1 Proximate composition of Schisandra chinensis (Turcz.) Baill. leaves

\begin{tabular}{lc}
\hline Component & Mean \pm SE \\
\hline Proteins & $12.38 \pm 0.16$ \\
Lipids (\%) & $4.36 \pm 0.09$ \\
Saturated fatty acids (g/100 g oil) & $54.40 \pm 0.16$ \\
Monounsaturated fatty acids (g/100 g oil) & $11.30 \pm 0.11$ \\
Polyunsaturated fatty acids (g/100 g oil) & $28.50 \pm 1.07$ \\
Fructose (g/kg) & $<0.5$ \\
Maltose (g/kg) & $<0.5$ \\
Sucrose (g/kg) & $<0.5$ \\
Lactose (g/kg) & $<0.5$ \\
Dry matter (\%) & $92.34 \pm 2.44$ \\
Ash (\%) & $5.70 \pm 0.17$ \\
Vitamin A (retinyl acetate) (mg/kg) & $<0.1$ \\
$\boldsymbol{\beta}$-carotene (mg/kg) & $17.70 \pm 0.10$ \\
Vitamin E ( $\alpha$-tocopherol) (mg/kg) & $48.58 \pm 2.66$ \\
\hline
\end{tabular}

Schisandra chinensis leaves proved to be rich in carotenoids, mainly $\beta$-carotene $(17.7 \mathrm{mg} / \mathrm{kg})$. Substantial share of $\beta$-carotene has a great impact on the colour, it is well known that carotenoids are one of the most common natural pigments protecting plants against photo-oxidative reactions. They are also the most effective antioxidants trapping molecular singlet oxygen and peroxyl radicals. At the same time, carotenoids enhance the effect of other antioxidants (Stahl and Sies, 2003).

The content of $\alpha$-tocopherol in leaves was assayed at the level of $48.58 \mathrm{mg} / \mathrm{kg}$. Vitamin E includes four tocopherols and tocotrienols, which main biochemical function is thought to bind organic peroxyl radicals (Shahidi and Ambigaipalan, 2015). These reactions determine the antioxidant activity of vitamin E, protecting tissue lipids from free radical attack.

The application of gas chromatography enabled determination of 20 fatty acid in lipid fraction extracted from Schisandra chinensis leaves belonged to all groups (Mišurcová etal., 2011) (Table 1 and 2); saturated -SFAs (54.4 g/100 g of the oil), monounsaturated - MUFAs (11.3 g/100 g of the oil), and polyunsaturated - PUFAs $(28.50 \mathrm{~g} / 100 \mathrm{~g}$ of the oil). The FA profile of leaves was represented mainly by palmitic (C16:0) $44.6 \mathrm{~g} / 100 \mathrm{~g}$ of oil, linoleic C18:2 9c12c $17.9 \mathrm{~g} / 100 \mathrm{~g}$ of oil, and $\alpha$-linolenic C18:3 9c12c15c $10.6 \mathrm{~g} / 100 \mathrm{~g}$ of oil acids (Table 2). The amount of these three FAs was $76.44 \%$ of the total FAs. The substancial presence of palmitic acid was confirmed in many previous studies; palmitic acid (27.7-60.0\%) dominated in the FA profile of leaf of many species from the Lamiaceae family (Cacan et al., 2018; Kilic, 2018); Cassia tora (L.) Roxb. (18.6-38.7 \%) (Shukla et al., 2018); Nicotiana species (13.0-18.0\%) (Koiwai et al., 1983); Cistus ladanifer L. (13.6-17.5 \%) (Jerónimo et al., 2020). In most cases, oleic acid is the second compound in the fatty acid profile (12.5\%). According to study of Kumar et al. (2009) oleic acid has insecticidal activity against Aedesae gyptii larvae. This FA was also detected in the FA profile of $S$. chinensis leaves (6.8\%).

Table 2 Fatty acid composition (g/100 g of oil) of lipids of Schisandra chinensis leaves

\begin{tabular}{lc}
\hline Fatty acid & Mean \pm SE \\
\hline SFAs & 7.63 \\
\hline C14:0 & $1.61 \pm 0.08$ \\
C16:0 & $44.60 \pm 1.58$ \\
C17:0 & $0.51 \pm 0.03$ \\
C18:0 & $3.94 \pm 0.08$ \\
C20:0 & $1.27 \pm 0.03$ \\
C22:0 & $1.16 \pm 0.04$ \\
C24:0 & $1.26 \pm 0.02$ \\
\hline MUFAs & 11.27 \\
\hline C16:1 & $3.99 \pm 0.05$ \\
C18:1 & $6.79 \pm 0.11$ \\
C20:1 & $0.49 \pm 0.03$ \\
\hline PUFAs & 28.49 \\
\hline C18:2 & $17.90 \pm 0.63$ \\
C18:3 & $10.59 \pm 0.48$ \\
\hline
\end{tabular}

Note: Saturated fatty acids - SFAs; monounsaturated fatty acids MUFAs; polyunsaturated fatty acids - PUFAs

Changes in FA composition of different morphological parts of the plants may be affected by abiotic stress such as extreme temperatures below and above zero and moisture deficiency (Gigon et al., 2004; Liu and Huang, 2004; Zhong et al., 2011; Li et al., 2017). Lipids play an important role in metabolic processes of organisms (Cakir, 2004). Also, it is well-known that FAs have antibacterial and antifungal properties (McGaw et al., 2002; Seidel and Taylor, 2004). Many studies indicated that a decreased risk of cardiovascular disease, coronary heart disease, cancer, hypertension, type 2 diabetes, kidney diseases, rheumatoid arthritis, ulcerative colitis, Crohn's disease, and osteoporosis, 


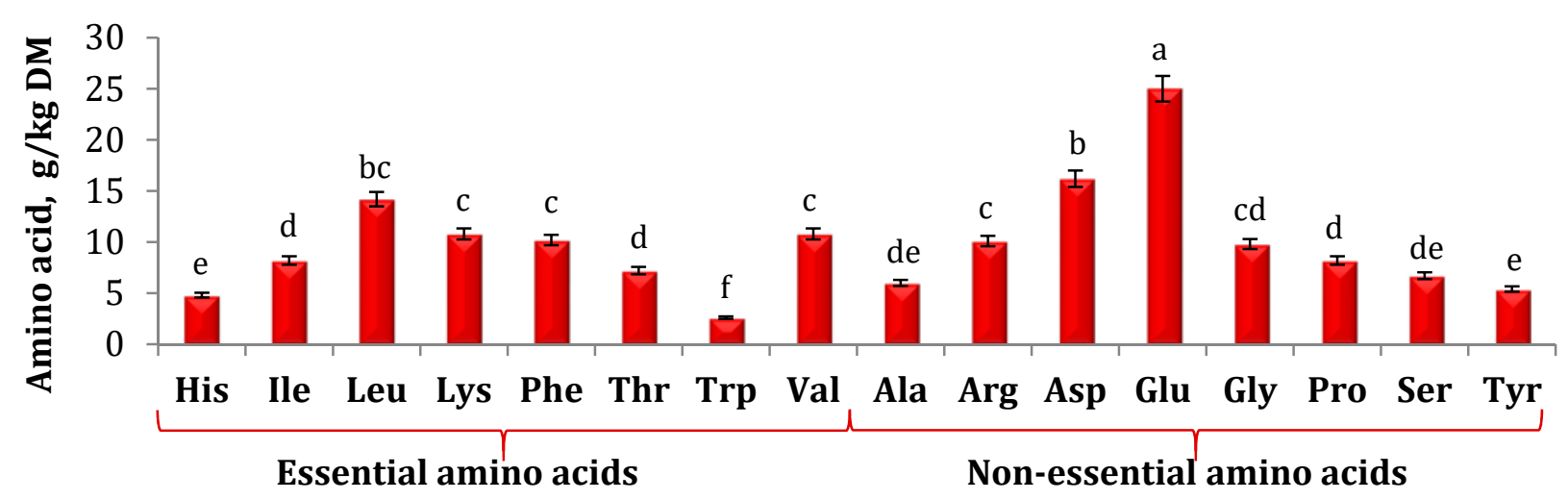

Figure 2 Amino acid composition (g/kg of dry matter; DM) of Schisandra chinensis leaves $\mathrm{a}, \mathrm{b}, \mathrm{c}, \mathrm{d}, \mathrm{e}, \mathrm{f}-$ different superscripts indicate the significant differences at $\mathrm{p}<0.05$

with consumption of PUFAs, especially FAs from n-3 family (De Caterina et al., 2000; Mišurcová et al., 2011; Abedi and Sahari, 2014). Our results indicated that Schisandra chinensis leaves may represent a novel potential plant source of FAs important for nutritional reasons.

Eighteen amino acids were detected in Schisandra chinensis leaves, nine of them were essential amino acids and nine non-essential ones (Figure 2).

The content of amino acids in leaves was at the level of $156.20 \mathrm{~g} / \mathrm{kg}$ of dry matter; while content of total essential amino acids was $68.80 \mathrm{~g} / \mathrm{kg}$ of dry matter (amounted $44.05 \%$ ) and $87.40 \mathrm{~g} / \mathrm{kg}$ of dry matter $(55.95 \%)$ for total non-essential amino acids. Glutamic acid was found to be the major component of nonessential amino acids ( $25 \mathrm{~g} / \mathrm{kg}$ of dry matter), followed by aspartic acid ( $16.2 \mathrm{~g} / \mathrm{kg}$ of dry matter) and leucine $(14.2 \mathrm{~g} / \mathrm{kg}$ of dry matter).

The contents of macroelements (K, P, S, Ca, Mg, Na), microelements ( $\mathrm{Zn}, \mathrm{Fe}, \mathrm{Cu}, \mathrm{Mn}, \mathrm{Cr}, \mathrm{Se}$ ), and metals (Al, $\mathrm{As}, \mathrm{Cd}, \mathrm{Ni}, \mathrm{Hg}, \mathrm{Pb}$ ) are presented in Table 3. Elements present in plants are responsible for their properties (including toxicity) since they are catalysts of most biochemical processes occurring in plants. Analysis of elements in leaves is an important guide to sustainable plant nutrition. The presence of trace elements and their content in plants are of considerable interest both from the theoretical point of view and of their medical application. In the etiology of many diseases, the imbalance of the content of trace elements in the human body plays an important role for mainatnance of good health (Penauelas et al., 2001; Erdal et al., 2006; Lipa, 2013; Yildirim et al., 2015).

Potassium (K) was the most abundant element in Schisandra chinensis leaves $(10209 \mathrm{mg} / \mathrm{kg}$ of dry weight of leaves), followed by $\mathrm{Ca}, \mathrm{P}$, and $\mathrm{Mg}$. It should be highlighted that potassium is an essential mineral, important mainly to maintain body water and to participate in transmitting nerve impulses to muscles, thus consumption of such leaves may have influence in covering daily required amount of this element. Regarding the presence of metals, the content of aluminium (Al; $32.1 \mathrm{mg} / \mathrm{kg}$ of dry weight of leaves) dominated among detected metals in Schisandra chinensis leaves. For maitanance of human health it is very important to study the contents of heavy metals, like for example $\mathrm{Cd}$, $\mathrm{Ni}$ and $\mathrm{Al}$, because some plants may have the tendency to accumulate toxic metals. Also, amounts of metals, especially toxic ones may provide useful information about environmental pollution levels.

Phenolic compounds are known as phytonutrients, secondary metabolites or bioactive compounds (Yoona et al., 2016). Phenolic compounds can prevent excessive free radicals and have positive health benefits such as anti-carcinogenic, anti-inflammatory activities, antibacterial, anti-diabetics, prevent neurodegenerative diseases such as Alzheimer's disease, Parkinson's disease, prion disease, and motor neurone disease (Siracusa et al., 2019), decrease the level of blood pressure, improvement of plasma lipid profile and endothelial function (Yoona et al., 2016).

The leaves of many non-traditional plants repersent promising source of antioxidants (Sakanaka et al., 2005; Priya and Nethaji, 2015; Ferlemi and Lamari, 2016; Klymenko et al., 2017; Urbanaviciute et al., 2019; Grygorieva et al., 2020b).

The spectrophotometric assays enabled detecting phenolic compounds belonging to; polyphenols, phenolic acids, and flavonoids, in Schisandra chinensis leaves. The content of polyphenols was $44.32 \mathrm{mg}$ 
Table 3 Elements composition of Schisandra chinensis leaves (mg/kg of dry weight)

\begin{tabular}{lc|}
\hline Element & mean \pm SE \\
\hline K & Macroelements \\
$\mathbf{P}$ & $3277 \pm 222$ \\
$\mathbf{C a}$ & $7330 \pm 310$ \\
$\mathbf{S}$ & $987 \pm 68$ \\
$\mathbf{M g}$ & $4012 \pm 412$ \\
$\mathbf{N a}$ & $28.0 \pm 0.9$ \\
\hline & Microelements \\
\hline $\mathbf{Z n}$ & $32.0 \pm 1.2$ \\
$\mathbf{F e}$ & $54.0 \pm 1.2$ \\
$\mathbf{C u}$ & $9.10 \pm 0.8$ \\
$\mathbf{M n}$ & $47.4 \pm 1.8$ \\
$\mathbf{C r}$ & $1.20 \pm 0.06$ \\
Se & $0.19 \pm 0.01$ \\
\hline & Metals \\
\hline Al & $32.1 \pm 1.9$ \\
As & $<0.3$ \\
$\mathbf{C d}$ & $0.114 \pm 0.002$ \\
$\mathbf{N i}$ & $0.49 \pm 0.02$ \\
$\mathbf{H g}$ & $0.017 \pm 0.002$ \\
\hline
\end{tabular}

GAE/g of dry leaves, total flavonoids - $29.16 \mathrm{mg} \mathrm{QE} / \mathrm{g}$ of dry leaves and phenolic acids $-6.12 \mathrm{mg} \mathrm{CAE} / \mathrm{g}$ of dry leaves (Figure 3).

According to study of Mocan et al. (2014), S. chinensis leaves contained more polyphenols $(62.36 \pm 1.38 \mathrm{mg} / \mathrm{g}$ DM) and flavonoids (35.10 $\pm 1.23 \mathrm{mg} / \mathrm{g}$ DM) compering with their fruits $(9.20 \pm 0.43$ and $7.65 \pm 0.95 \mathrm{mg} / \mathrm{g}$ d.w., respectively).

According to previously published data, leaves of cultivated and wild plants are a valuable source of polyphenols and flavonoids. Thus, the TPC in Mangifera indica L. leaves was at the level of $65 \mathrm{mg} / \mathrm{g}$, Anacardium occidentale L. $-58.57 \mathrm{mg} / \mathrm{g}$. Moreover, TPC determined in ethanolic extracts of Cymbopogm citrates leaves was $28.30 \mathrm{mg} / \mathrm{g}$, Carica papaya L. leaves $-21.80 \mathrm{mg} / \mathrm{g}$ (Iyawe and Azih, 2011), Euphorbia spp. leaves 19.10-20.30 mg/g (Gapuz and Besagas, 2018), Azadirachta indica Juss leaves $14.43 \mathrm{mg} / \mathrm{g}$ (Iyawe and Azih, 2011). According to Thi and Hwang (2014), the polyphenol content of Aronia mitschurinii leaves ranges from 139.3 to $250.8 \mathrm{mg} \mathrm{GAE} / \mathrm{g}$ of DM. However, results of TPC of Shahin et al. (2019) were significantly higher - $765.63 \mathrm{mg} \mathrm{GAE} / \mathrm{g}$ of dried leaves of Aronia melanocarpa. According to Męczarska et al. (2017), the leaves of Amelanchier alnifolia had a polyphenol content at the level of $185.23 \mathrm{mg} \mathrm{GAE} / \mathrm{g} \mathrm{DM}$.

Research of Barreira et al. (2010) and Stankovic et al. (2014), who studied total flavonoid content of leaves of Castanea sativa Mill., indicated that the flavonoids content was up to 3-fold higher (73.31-90.39 mg/g) compering with our results of flavonoids of Schisandra chinensis leaves. It was proved that methanolic extracts were the richest in flavonoids: TFC was $90.28 \mathrm{mg} / \mathrm{g}$ of methanolic extracts of Ziziphus jujuba Mill. leaves, while in the ethanolic extract the TFC was only $22.18 \mathrm{mg} / \mathrm{g}$ (Al-Saeedi et al., 2016). Grygorieva et al. (2020b) studied the content of phenolic compounds in the leaves of several non-traditional plants. The Lycium barbarum leaves distinguished by the highest content of polyphenols and flavonoids (95.84 mg GAE/g and $54.61 \mathrm{mg} \mathrm{QE} / \mathrm{g}$, respectively).

The antioxidant activity of $S$. chinensis leaves, as determined by DPPH•, was at the level of $9.19 \mathrm{mg}$ TEAC/g of DW, and $214 \mathrm{mg}$ TEAC/g of DW (as determind by molybdenum reducing antioxidant power - MRAP; Figure 3). For the comparison, the radical scavenging activity (DPPH) of some other plant leaves is lower than assayed for S. chinensis leaves: Aronia mitschurinii leaves - $6.92 \mathrm{mg}$ TEAC/g of DM; Cornus mas - $9 \mathrm{mg}$

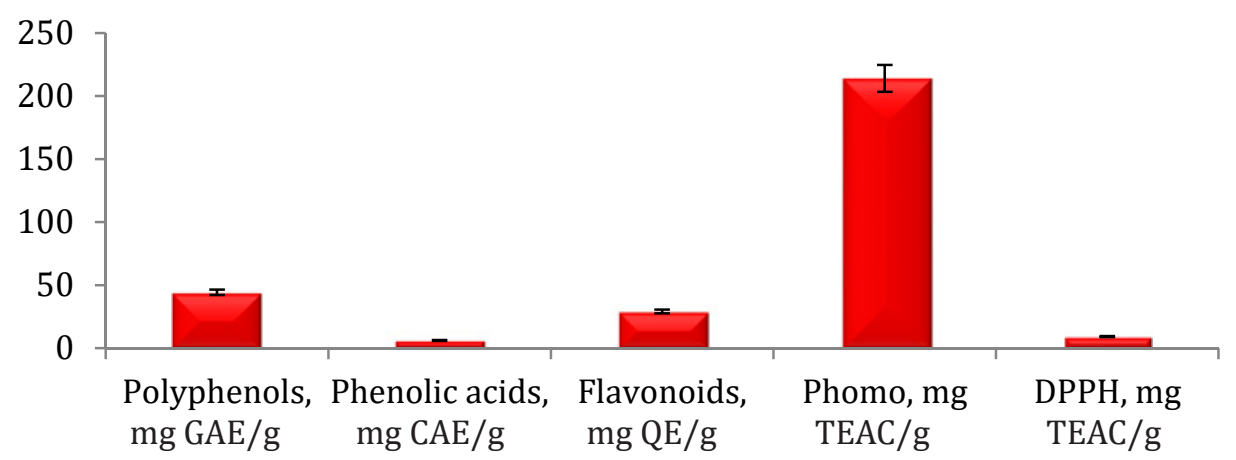

Figure 3 Bioactive compounds and antioxidant potential of Schisandra chinensis leaves 
TEAC/g of DM. Antioxidant activity determined by molybdenum reducing antioxidant power ranged from $109.43 \mathrm{mg} \mathrm{TEAC} / \mathrm{g}$ of DM (A. mitschurinii leaves) to $322.95 \mathrm{mg}$ TEAC/g of DM (C. mas leaves) (Grygorieva et al., 2020b).

Some previous studies were also focused on the composition of $S$. chinensis plant and its products (Tvrdá et al., 2020). The antioxidant capacity of S. chinensis essential oil, measured by DPPH test $\left(\mathrm{IC}_{50}\right)$, was determined as $4.17 \mathrm{mg} / \mathrm{mL}$ (Chen et al., 2012b), while the free-radical scavenging activity of the extract was $5.93 \mathrm{mg}$ TEAC/g of DM. According to the MRAP assay, the antioxidant activity of the extract was 140.52 mg TEAC/g of DM. The TPC of the extract was 16.52 $\mathrm{mg} \mathrm{GAE} / \mathrm{g}$ of DM, the TFC was $2.66 \mathrm{mg} \mathrm{QE} / \mathrm{g}$ of DM and the carotenoids content was $0.15 \mathrm{mg} \beta$-carotene/g of DM (Tvrdá et al., 2020). Also, antioxidant activity of $S$. chinensis berries was studied previously by Ivanišová et

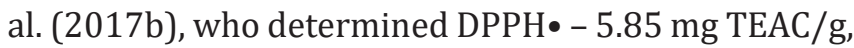
MRAP - $148.87 \mathrm{mg}$ TEAC/g, and TPC - $15.55 \mathrm{mg} \mathrm{GAE} / \mathrm{g}$ of berries. Compering these findings with our results for antioxidant properties of $S$. chinensis leaves, it can be concluded that not only $S$. chinensis berries but also leaves posses fairy good antioxidant capacity.

Hamauzu et al. (2006) described that the fruits and leaves of Schisandra chinensis are a valuable natural source of caffeoylquinic acid and epicatechin. High levels of antioxidants and antiproliferative compounds make it possible to recommend this species for use in pharmaceutical and therapeutic nutrition, for the prevention and treatment of such human pathologies as cardiovascular disease and cancer.

Since the leaves of Schisandra chinensis are an inexpensive natural source of bioactive components, the extract from them can be used for the prevention and treatment of atherosclerosis, hypertrophic heart disease, hypertension, and diabetes.

\section{Conclusions}

This study demonstrates that Schisandra chinensis leaves may be regarded as a valuable source of minerals: $\mathrm{K}(10209 \mathrm{mg} / \mathrm{kg}$ of dry weight of leaves), Ca, P, Mg, and phenolic compounds (polyphenols - $44.32 \mathrm{mg}$ GAE/g of dry leaves), with fairly good antioxidant activity (DPPH• test $-9.19 \mathrm{mg}$ TEAC/g of dry leaves, and MRAP test - $214 \mathrm{mg}$ TEAC/g of dry leaves). The $\beta$-carotene content was $17.7 \mathrm{mg} / \mathrm{kg}$. The fatty acid profile of leaves was represented by palmitic C16:0 (44.6 g/100 g of oil), linoleic C18:2 9c12c (17.9 g/100 $\mathrm{g}$ of oil), and $\alpha$-linolenic C18:3 (9c12c15c $10.6 \mathrm{~g} / 100$ $\mathrm{g}$ of oil) acids. Nine out of 18 amino acids detected in leaves were essential amino acids $(68.80 \mathrm{~g} / \mathrm{kg}$ of dry leaves), with significant share of glutamic acid $(25 \mathrm{~g} /$ $\mathrm{kg}$ of dry weight), followed by aspartic acid $(16.2 \mathrm{~g} / \mathrm{kg}$ of dry weight) and leucine (14.2 g/kg of dry weight). The established composition of Schisandra chinensis leaves suggest it to become an inexpensive novel plant source of functional foods, supplements, and as a new ingredient in human diet.

\section{Conflicts of Interest}

The authors declare no conflict of interest.

\section{Ethical Statement}

This article does not contain any studies that would require an ethical statement.

\section{Funding}

This work was supported by grant Visegrad Fund for the scholarship for the research during which the presented knowledge was obtained.

\section{Acknowledgments}

The publication was prepared with the active participation of researchers in International Network AgrobioNet.

\section{References}

Abedi, E., \& Sahari, M.A. (2014). Long-chain polyunsaturated fatty acid sources and evaluation of their nutritional and functional properties. Food Science and Nutrition, 2(5), 443-463. https://doi.org/10.1002/fsn3.121

Al-Saeedi, A.H., Al-Ghafri, M.T.H., \& Hossain, M.A. (2016). Comparative evaluation of total phenols, flavonoids content and antioxidant potential of leaf and fruit extracts of Omani Ziziphus jujuba L. Pacific Science Review A: Natural Science and Engineering, 18(1), 7883. https://doi.org/10.1016/j.psra.2016.09.001

AOCS, American Oil Chemist's Society, 1997.

Barreira, J.C.M., Ferreira, I.C.F.R., Oliveira, M.B.P.P., \& Pereira, J.A. (2010). Antioxidant potential of chestnut (Castanea sativa L.) and almond (Prunus dulcis L.) by-products. Food Science and Technology International, 16(3), 209216. http://dx.doi.org/10.1177/1082013209353983

Cacan, E., Kokten, K., \& Kilic, O. (2018). Leaf fatty acid composition of some Lamiaceae taxa from Turkey. Progress in Nutrition, 20(1), 231-236. https://doi.org/10.23751/pn.v20i1-S.5930

Cakir, A. (2004). Essential oil and fatty acid composition of the fruits of Hippophae rhamnoides L. (Sea Buckthorn) and Myrtus communis L. from Turkey. Biochemical Systematics and Ecology, 32(9), 809-816. https://doi.org/10.1016/j.bse.2003.11.010 
Chen, X., Zhang, Y., Zu, Y., \& Yang, L. (2012b). Chemical composition and antioxidant activity of the essential oil of Schisandra chinensis fruits. Natural Product Research: Formerly Natural Product Letters, 26(9), 842-849. http://dx.doi.org/10.1080/14786419.2011.558016

Chen, X., Zhang, Y., Zu, Y., Fu, Y., \& Wang, W. (2011). Composition and biological activities of the essential oil from Schisandra chinensis obtained by solvent-free microwave extraction. LWT-Food Science and Technology, 44, 2047-2052.

https://doi.org/10.1016/j.lwt.2011.05.013

Chen, Y., Tang, J., Wang, X., Sun, F., \& Liang, S. (2012a). An immunostimulatory polysaccharide (SCP-IIa) from the fruit of Schisandra chinensis (Turcz.) Baill. International Journal of Biological Macromolecules, 50, 844-848. https://doi.org/10.1016/j.ijbiomac.2011.11.015

Chiu, P.Y., Lam, P.Y., Yan, C.W., \& Ko, K.M. (2011). Schisandrin $B$ protects against solar irradiation-induced oxidative injury in BJ human fibroblasts. Fitoterapia, 82(4), 682691. http://dx.doi.org/10.1016/j.fitote.2011.02.010

Chiu, P.Y., Luk, K.F., Leung, H.Y., \& Ng, K.M. (2008). Schisandrin B stereoisomers protect against hypoxia/ reoxygenation-induced apoptosis and inhibit associated changes in $\mathrm{Ca}^{2+}$-induced mitochondrial permeability transition and mitochondrial membrane potential in H9c2 cardiomyocytes. Life Sciences, 82, 1092-1101. http://dx.doi.org/10.1016/j.lfs.2008.03.006

Ciorchină, N., Onica, E., Roșca, I., Dumitraș, A., Clapa, D., \& Fira, A. (2011). The biology of the propagation of species Schisandra chinensis (Turcz.) Baill. Journal of Plant Development, 18, 17-26.

De Caterina, R., Liao, J.K., \& Libby, P. (2000). Fatty acid modulation of endothelial activation. American Journal of Clinical Nutrition, 71(1), 213S-223S. https://doi.org/10.1093/ajcn/71.1.213S

Dweck, A.C., \& Marshall, N. (2009). Much new presented at Munich show. Cosmet Rev, 6, 13-21.

Ekiert, R., Szopa, A., Ekiert, H., Krzek, J., \& Dzik, E. (2013). Analysis of lignans in Schisandra chinensis fruits, leaves, biomasses from in vitro cultures and food supplements. Journal of Functional Foods, 5, 1576-1581. https://doi.org/10.1016/j.jff.2013.06.008

Erdal, I., Kepenek, K., \& Kizilgöz, I. (2006). Effects of elemental sulphur and sulphur containing waste on the iron nutrition of strawberry plants grown in a calcareous soil. Biological Agriculture and Horticulture, 23(3), 263272. https://doi.org/10.1080/01448765.2006.9755328

Farmakopea Polska. (1999). Poland: The Polish Farmaceutical Society. Poland: The Polish Farmaceutical Society.

Ferlemi, A.-V., \& Lamari, F.N. (2016). Berry leaves: an alternative source of bioactive natural products of nutritional and medicinal value. Antioxidants, 5(2), 17. https://doi.org/10.3390/antiox5020017

Gapuz, M.C.D., \& Besagas, R.L. (2018). Phytochemical profiles and antioxidant activities of leaf extracts of Euphorbia species. Journal of Biodiversity and Environmental Sciences, 12(4), 59-65.
Gigon, A., Matos, A., Laffray, D., Zuily-Fodil, Y., \& Pham-Thi, A. (2004). Effect of drought stress on lipid metabolism in the leaves of Arabidopsis thaliana (Ecotype Columbia). Annals of Botany (Lond.), 94, 345-351. https://doi.org/10.1093/aob/mch150

Grygorieva, O., Klymenko, S., Brindza, J., Schubertová, Z., Nikolaieva, N., \& Šimková, J. (2017). Morphometric characteristics of sweet chestnut (Castanea sativa Mill.) fruits. Potravinarstvo Slovak Journal of Food Sciences, 11(1), 288-295. https://doi.org/10.5219/684

Grygorieva, O., Klymenko, S., Ilinska, A., \& Brindza, J. (2018a). Variation of fruits morphometric parameters of Elaeagnus multiflora Thunb. germplasm collection. Potravinarstvo Slovak Journal of Food Sciences, 12(1), 527-532. https://doi.org/10.5219/922

Grygorieva, O., Klymenko, S., Vergun, O., Shelepova, O., Vinogradova, Y., Ilinska, A., Horčinová Sedláčková, V., \& Brindza, J. (2020a). Chemical composition of leaves of chinese quince (Pseudocydonia sinensis (Thouin) C.K. Schneid.).AgrobiodiversityforImproving Nutrition, Health and Life Quality, 4, 78-93. https://doi.org/10.15414/ agrobiodiversity.2020.2585-8246.078-93

Grygorieva, O., Klymenko, S., Vinogradova, Y., Vergun, O., \& Brindza, J. (2018b). Variation in morphometric traits of fruits of Mespilus germanica L. Potravinarstvo Slovak Journal of Food Sciences, 12(1), 782-788.

https://doi.org/10.5219/999

Grygorieva, O., Kucharska, A.Z., Piórecki, N., Klymenko, S., Vergun, O., \& Brindza, J. (2018c). Antioxidant activities and phenolic compounds in fruits of various genotypes of American persimmon (Diospyros virginiana L.). Acta Scientiarum Polonorum Technologia Alimentaria, 17(2), 117-124. http://doi.org/10.17306/J.AFS.0544

Grygorieva, O., Vergun, O., Klymenko, S., Zhurba, M., Horčinová Sedláčková, V., Ivanišová, E., \& Brindza, J. (2020b). Estimation of phenolic compounds content and antioxidant activity of leaves extracts of some selected non-traditional plants. Potravinarstvo Slovak Journal of Food Sciences, 14, 501-509. https://doi.org/10.5219/1314

Hakala, E., Hanski, L., Uvell, H., Yrjönen, T., Vuorela, H., Elofsson, M., \& Vuorela, P.M. (2015). Dibenzocyclooctadiene lignans from Schisandra spp. selectively inhibit the growth of the intracellular bacteria Chlamydia pneumoniae and Chlamydia trachomatis. Journal of Antibiotics, 68, 609-614.

https://doi.org/10.1038/ja.2015.48

Halford, N.G., Curtis, T.Y., Muttucumaru, N., Postles, J., \& Mottram, D.S. (2011). Sugars in crop plants. Annals of Applied Biology, 158(1), 1-25. https://doi.org/10.1111/j.1744-7348.2010.00443.x

Hamauzu, Y., Inno, T., Kume, C., Irie, M., \& Hiramatsu, K. (2006). Antioxidant and antiulcerative properties of phenolics from Chinese quince, quince, and apple fruits. Journal of Agricultural and Food Chemistry, 54(3), 765772. http://dx.doi.org/10.1021/if052236y

Hancke, J.L., Burgos, R.A., \& Ahumada, F. (1999). Schisandra chinensis (Turcz.) Baill. Fitoterapia, 70, 451-471. 
Horčinová Sedláčková, V., Grygorieva, O., Fatrcová Šramková, K., Vergun, O., Vinogradova, Y., Ivanišová, E., \& Brindza, J. (2018). The morphological and antioxidant characteristics of inflorescences within wild-growing genotypes of elderberry (Sambucus nigra L.). Potravinarstvo Slovak Journal of Food Sciences, 12(1), 444-453. https://doi.org/10.5219/919

Horčinová Sedláčková, V., Grygorieva, O., Vergun, O.M., Vinogradova, Ju.K., \& Brindza, J. (2019). Comparison of selected characteristics of cultivars and wild-growing genotypes of Sambucus nigra in Slovakia. Biosystems Diversity, 27, 56-61. https://doi.org/10.15421/011909

Hu, D., Yang, Z., Yao, X., Wang, H., Han, N., Liu, Z., Wang, Y., Yang, J., \& Yin, J. (2014). Dibenzocyclooctadiene lignans from Schisandra chinensis and their inhibitory activity on NO production in lipopolysaccharide-activated microglia cells. Phytochemistry, 104, 72-78. https://doi.org/10.1016/j.phytochem.2014.04.014

Hwang, D., Shin, S.Y., Lee, Y., Hyun, J., Yong, Y., Park, J.C., Lee, Y.H., \& Lim, Y. (2011). A compound isolated from Schisandra chinensis induces apoptosis. Bioorganic \& Medicinal Chemistry Letters, 21, 6054-6057. https://doi.org/10.1016/j.bmcl.2011.08.065

Ivanišová, E., Grygorieva, O., Abrahamová, V., Schubertova, Z., Terentjeva, M., \& Brindza, J. (2017a). Characterization of morphological parameters and biological activity of jujube fruit (Ziziphus jujuba Mill.). Journal of Berry Research, 7(4), 249-260.

https://doi.org/10.3233/JBR-170162

Ivanišová, E., Mittuchová, K., Mareček, J., \& Frančáková, H. (2017b). Small berries-attractive source of bioactive compounds for consumers. Agrobiodiversity for Improving Nutrition, Health and Life Quality, 1, 188-194.

Iyawe, H.O.T., \& Azih, M.C. (2011). Total phenolic contents and lipid peroxidation potentials of some tropical antimalarial plants. European Journal of Medicinal Plants, 1, 33-39. http://dx.doi.org/10.9734/EJMP/2011/171

Jeong, E.J., Lee, H.K., Lee, K.Y., Jeon, B.J., Kim, D.H., Park, J.H., Song, J.H., Huh, J., Lee, J.H., \& Sung, S.H. (2013). The effects of lignan-riched extract of Shisandra chinensis on amyloid- $\beta$-induced cognitive impairment and neurotoxicity in the cortex and hippocampus of mouse. Journal of Ethnopharmacology, 146, 347-354. http://dx.doi.org/10.1016/j.jep.2013.01.003

Jerónimo, E., Cachucho, L., Soldado, D., Guerreiro, O., Bessa, R.J.B., \& Alves, S.P. (2020). Fatty acid content and composition of the morphological fractions of Cistus ladanifer L. and its seasonal variation. Molecules, 25(7), 1550. http://dx.doi.org/10.3390/molecules 25071550

Kilic, Ö. (2018). Essential oil and fatty acid composition of leaves of some Lamiaceae taxa from Turkey. Journal of Essential Oil Bearing Plants, 21(6), 1706-1711. http://dx.doi.org/10.1080/0972060x.2018.1538820

Klymenko, S., Grygorieva, O., Brindza, J. (2017). Maloizvestnye vidy plodovyh kultur [Less known species of fruit crops]. Nitra, Slovakia : SUA. [in Russian]. http://dx.doi.org/10.15414/2017.fe-9788055217659
Klymenko, S., Kucharska, A. Z., Sokół-Łętowska, A., \& Piórecki, N. (2019). Antioxidant activities and phenolic compounds in fruits of cultivars of cornelian cherry (Cornus mas L.). Agrobiodiversity for Improving Nutrition, Health and Life Quality, 3, 484-499. https://doi. org/10.15414/agrobiodiversity.2019.2585-8246.484-4

Koiwai, A., Suzuki, F., Matsuzaki, T., \& Kawashima, N. 1983. The fatty acid composition of seeds and leaves of Nicotiana species. Phytochemistry, 22(6), 1409-1412. http://dx.doi.org/10.1016/s0031-9422(00)84024-8

Kumar, A., Ilavarasan, R., Jayachandran, T., Decaraman, M., Aravindhan, P., Padmanabhan, N., \& Krishnan, M.R.V. (2009). Phytochemical investigation on a tropical plant, Syzygium cumini from Kattuppalayam, Erode District, Tamil Nadu, South India. Pakistan Journal of Nutrition, 8(1), 83-85. http://dx.doi.org/10.3923/pjn.2009.83.85

Li, Y., Li, Y., Yang, P., Zhang, H., \& He, D. (2017). Phospholipid and fatty acid composition in leaves and roots of ten autumn chrysanthemum cultivars grown at low temperature. Horticulture, Environment, and Biotechnology, 58(4), 334-341. http://dx.doi.org/10.1007/s13580-017-0227-9

Lipa, T. (2013). Changes in chemical composition of leaves and shoots during vegetation of apple-tree rootstocks in mother plantation. Electronic Journal of Polish Agricultural Universities, 16(2), \#08. Available at:

http://www.ejpau.media.pl/volume16/issue2/art-08.html

Liu, X., \& Huang, B. (2004). Changes in fatty acid composition and saturation in leaves and roots of creeping bentgrass exposed to high soil temperature. Journal American Society Horticultural Science, 129(6), 795-801. https://doi.org/10.21273/JASHS.129.6.0795

Mcgaw, L.J., Jäger, A.K., \& Van Staden, J. (2002). Isolation of antibacterial fatty acids from Schotia brachypetala. Fitoterapia, 73(5), 431-433. https://doi.org/10.1016/S0367-326X(02)00120-X

Męczarska, K., Cyboran-Mikołajczyk, S., Włoch, A., BonarskaKujawa, D., Oszmiański, J., \& Kleszczyńska, H. (2017). Polyphenol content and bioactivity of saskatoon (Amelanchier alnifolia Nutt.) leaves and berries. Acta Polonia Pharmaceutica - Drug Research, 74(2), 660-669.

Merdzhanov, P., Delchev, N., Teneva, O., Gochev, V., \& Stoyanova, A. (2016). Phytochemistry of Schizandra chinensis (Turcz.) Baill cultivated in Bulgaria. Medicinal and Aromatic Crops: Production, Phytochemistry, and Utilization, 235-245. https://doi.org/10.1021/bk-2016-1218.ch014

Mišurcová, L., Ambrožová, J., \& Samek, D. (2011). Seaweed lipids as nutraceuticals. Advances in Food and Nutrition Research, 64, 339-355. https://doi.org/10.1016/B978-0-12-387669-0.00027-2

Mocan, A., Crişan, G., Vlase, L., Crișan, O., Vodnar, D.C., Raita, O., Gheldiu, A.M., Toiu, A., Oprean, R., \& Tilea, I. (2014). Comparative studies on polyphenolic composition, antioxidant and antimicrobial activities of Schisandra chinensis leaves and fruits. Molecules, 19, 15162-15179. https://doi.org/10.3390/molecules190915162 
Monka, A., Grygorieva, O., Chlebo, P., \& Brindza, J. (2014). Morphological and antioxidant characteristics of quince (Cydonia oblonga Mill.) and chinese quince fruit (Pseudocydonia sinensis Schneid.). Potravinarstvo Slovak Journal of Food Sciences, 8(1), 333-340. https://doi.org/10.5219/415

Panossian, A., \& Wikman, G. (2008). Pharmacology of Schisandra chinensis Bail.: an overview of Russian research and uses in medicine. Journal of Ethnopharmacology, 118, 183-212.

Park, H.J., Cho, J.Y., Kim, M.K., Koh, P.-O., Cho, K.-W., Kim, C.H., Lee, K.-S., Chung, B.Y., Kim, G.-S., \& Cho, J.-H. (2012). Antiobesity effect of Schisandra chinensis in 3T3-L1 cells and high fat diet-induced obese rats. Food Chemistry, 134, 227234. https://doi.org/10.1016/i.foodchem.2012.02.101

Penauelas, J., Filella, I., \& Tognettir, R. (2001). Leaf mineral concentrations of Erica arborea, Juniperus communis and Myrtus communis growing in the proximity of a natural C02 spring. Global Change Biology, 7(3), 291-301. https://doi.org/10.1046/j.1365-2486.2001.00409.x

Prieto, P., Pinera, M., \& Aguilar, M. (1999). Spectrophotometric quantitation of antioxidant capacity through the formation of a phosphomolybdenum complex: Specific application to the determination of vitamin E. Analytical Biochemistry, 269, 334-337. https://doi.org/10.1006/abio.1999.4019

Priya, S., \& Nethaji, S. (2015). Evaluation of antioxidant activity of leaf and bark extracts of Diospyros virginiana in rats. International Journal of ChemTech Research, $8(3)$, p. 1032-1035.

Quirin, K.W. (2008). Supercritical schisandra extracts a new concept for personal care cosmetics. Cosmetic Science and Technology, 1, 28.

Sa, F., Zhang, L.Q., Chong, C.M., Guo, B.J., Li, S., Zhang, Z.J., Zheng, Y., Hoi, P.M., \& Lee, S.M. (2015). Discovery of novel anti-parkinsonian effect of schisantherin A in in vitro and in vivo. Neuroscience Letters, 593, 7-12. https://doi.org/10.1016/j.neulet.2015.03.016

Sakanaka, S., Tachibana, Y., \& Okada, Y. (2005). Preparation and antioxidant properties of extracts of Japanese persimmon leaf tea (kakinohacha). Food Chemistry, 89, 569-575.

Sanches-Moreno, C., Larrauri, A., \& Saura-Calixto, F. (1998). A procedure to measure the antioxidant efficiency of polyphenols. Journal of Sciences and Food Agricultural, 76(2), 270-276. https://doi.org/10.1002/(SICI)10970010(199802)76:2<270::AID-JSFA945>3.0.C0;2-9

Sarker, U., \& Oba, S. (2019). Protein, dietary fiber, minerals, antioxidant pigments and phytochemicals, and antioxidant activity in selected red morph Amaranthus leafy vegetable. PLOS One., 14(12), e0222517. https://doi.org/10.1371/journal.pone.0222517

Seidel, V., \& Taylor, P.W. (2004). In vitro activity of extracts and constituents of Pelargonium against rapidly growing mycobacteria. International Journal of Antimicrobial Agents, 23(6), 613-619.

https://doi.org/10.1016/j.ijantimicag.2003.11.008
Shafii, Z. A., Basri, M., Malek, E. A., \& Ismail, M. (2017). Phytochemical and antioxidant properties of Manilkara zapota (L.) $\mathrm{P}$ roen fruit extracts and its formulations for cosmeuetical application. Asian Journal of Plant Science and Research, 7, 29-41.

Shahidi, F., \& Ambigaipalan, P. (2015). Phenolics and polyphenolics in foods, beverages and spices: antioxidant activity and health effects - a review. Journal of Functional Foods, 18, 820-897. https://doi.org/10.1016/j.jff.2015.06.018

Shahin, L., Phaal, S.S., Vaidya, B.N., Brown, J.E., \& Joshee, N. (2019). Aronia (Chokeberry): an underutilized, highly and nutraceutical plant. Journal of Medicinally Active Plants, 8(4), 46-63.

Shukla, S.H., Hegde, S., Kumar, A., Chaudhary, G., Tewari, Sh.K., Upreti, D.K., \& Pal, M. (2018). Fatty acid composition and antibacterial potential of Cassia tora (leaves and stem) collected from different geographic areas of India. Journal of Food and Drug Analysis, 26(1), 107-111. http://dx.doi.org/10.1016/j.jfda.2016.12.010

Singleton, V.L., \& Rossi, J.A. (1965). Colorimetry of total phenolics with phosphomolybdic-phosphotungstic acid reagents. American Journal of Enology and Agricultural, 6, 144-158.

Siracusa, L., \& Ruberto, G. (2019). Not only what is food is good - Polyphenols from edible and nonedible vegetable waste. Polyphenolsin Plants. Elsevier: Amsterdam, The Netherlands.

Stahl, W., \& Sies, H. (2003). Antioxidant activity of carotenoids. Molecular Aspects of Medicine, 24(6), 345-351. https://doi.org/10.1016/S0098-2997(03)00030-X

Stankovic, M.S., Zia-Ul-Haq, M., Bojovic, B.M., \& Topuzovic, M.D. (2014). Total phenolics, flavonoid content and antioxidant power of leaf, flower and fruits from cornelian cherry (Cornus mas L.). Bulgarian Journal of Agricultural Science, 20(2), 358-363.

Szabóová, M., Záhorský, M., Gažo, J., Geuens, J., Vermoesen, A., D’Hondt, E., \& Hricová, A. (2020). Differences in seed weight, amino acid, fatty acid, oil, and squalene content in $\gamma$-irradiation-developed and commercial Amaranth varieties (Amaranthus spp.). Plants, 9, 1412. https://doi.org/10.3390/plants9111412

Szopa, A., \& Ekiert, H. (2014). Schisandra chinensis (Turcz.) Baill. (Chinese magnolia vine) in vitro cultures. Govil JN (ed) Recent progress in medicinal plants. Biotechnology and genetic engineering II. vol. 39. Houston: Studium Press LLC.

Thandavarayan, R.A., Giridharan, V.V., Arumugam, S., Suzuki, K., Ko, K.M., Krishnamurthy, P., Watanabe, K., \& Konishi, T. (2015). Schisandrin B prevents doxorubicin induced cardiac dysfunction by modulation of DNA damage, oxidative stress and inflammation through inhibition of MAPK/p53 signaling. PLoS One, vol. 10(3), e0119214. https://doi.org/10.1371/journal.pone.0119214

Thi, N.D., \& Hwang, E.-S. (2014). Bioactive compound contents and antioxidant activity in aronia (Aronia melanocarpa) 
leaves collected at different growth stages. Preventive Nutrition and Food Science, 19(3), 204-212. http://dx.doi.org/10.3746/pnf.2014.19.3.204

Tong, H., Zhao, B., Du, F., Tian, D., Feng, K., \& Sun, X. (2012). Isolation and physicochemical characterization of polysaccharide fractions isolated from Schisandra chinensis. Chemistry of Natural Compounds, 47, 969970. https://doi.org/10.1007/s10600-012-0116-5

Tvrdá, E., Michalko, J., Árvay, J., Vukovic, N.L., Ivanišová, E., Ďuračka, M., Matušíková, I., \& Kačániová, M. (2020). Characterization of the Omija (Schisandra chinensis) extract and its effects on the bovine sperm vitality and oxidative profile during in vitro storage. Evidence-Based Complementary and Alternative Medicine, 2020, Article ID 7123780, $15 \mathrm{pp}$.

https://doi.org/10.1155/2020/7123780

Urbanaviciute, I., Liaudanskas, M., Seglina, D., \& Viskelis, P. (2019). Japanese quince Chaenomeles Japonica (Thunb.) Lindl. ex Spach leaves a new source of antioxidants for food. International Journal of Food Properties, 22(1), 795-803.

https://doi.org/10.1080/10942912.2019.1609984

Vinogradova, Y., Vergun, O., Grygorieva, O., Ivanišová, E., \& Brindza, J. (2020). Comparative analysis of antioxidant activity and phenolic compounds in the fruits of Aronia spp. Potravinarstvo Slovak Journal of Food Sciences, 14, 393-401. https://doi.org/10.5219/1360

Wang, X., Yu, J., Li, W., Wang, C., Li, H., Ju, W., Chen, J., \& Sun, J. (2018). Characteristics and antioxidantactivity oflignans in Schisandra chinensis and Schisandra sphenanthera from different locations. Chemistry \& Biodiversity, 15(6), e1800030. https://doi.org/10.1002/cbdv.201800030

Wind, J., Smeekens, S., \& Hanson, J. (2010). Sucrose: Metabolite and signaling molecule. Phytochemistry, 71(14-15), 1610-1614.

https://doi.org/10.1016/j.phytochem.2010.07.007

Wu, X., Yu, X., \& Jing, H. 2011. Optimization of phenolic antioxidant extraction from Wuweizi (Schisandra chinensis) pulp using random-centroid optimization methodology. International Journal of Molecular Sciences, 12, 6255-6266. https://doi.org/10.3390/ijms12096255
Xia, Y.G., Yang, B.Y., \& Kuang, H.X. (2015). Schisandraceae triterpenoids: a review. Phytochemistry Reviews, 14, 155187. https://doi.org/10.1007/s11101-014-9343-7

Xu, L., Grandi, N., Del Vecchio, C., Mandas, D., Corona, A., Piano, D., Esposito, F., Parolin, C., \& Tramontano, E. (2015). From the traditional Chinese medicine plant Schisandra chinensis new scaffolds effective on HIV-1 reverse transcriptase resistant to non-nucleoside inhibitors. Journal of Microbiology, 53, 288-293. https://doi.org/10.1007/s12275-015-4652-0

Yildirim, F., Şan, B., Yildirim, A.N., Polat, M., \& Ercişli, S. (2015). Mineral composition of leaves and fruit in some myrtle (Myrtus communis L.) genotypes. Erwerbs-Obstbau, 57, 149-152. https://doi.org/10.1007/s10341-015-0243-9

Yim, S.Y., Lee, Y.J., Lee, Y.K., Jung, S.E., Kim, J.H., Kim, H.J., Son, B.G., Park, Y.H., Lee, Y.G., Choi, Y.W., \& Hwang, D.Y. (2009). Gomisin N isolated from Schisandra chinensis significantly induces anti-proliferative and pro-apoptotic effects in hepatic carcinoma. Molecular Medicine Reports, 2, 725-732. https://doi.org/10.3892/mmr 00000163

Yoona, K., Keogh, J.B., \& Clifton, P.M. (2016). Polyphenols and glycemic control. Nutrients, 8(1), 17. https://doi.org/10.3390/nu8010017

Zhao, T., Mao, G., Mao, R., Zou, Y., Zheng, D., Feng, W., Ren, Y., Wang, W., Zheng, W., Song, J., Chen, Y., Yang, L., \& $\mathrm{Wu}, \mathrm{X}$. (2013). Antitumor and immunomodulatory activity of a water-soluble low molecular weight polysaccharide from Schisandra chinensis (Turcz.) Baill. Food and Chemical Toxicology, 55, 609-616. https://doi.org/10.1016/j.fct.2013.01.041

Zhong, D., Du, H., \& Wang, Z.H. (2011). Genotypic variation in fatty acid composition and unsaturation levels in Bermudagrass Associated with leaf dehydration tolerance. Journal of the American Society for Horticultural Science, 136(1), 35-40. https://doi.org/10.21273/JASHS.136.1.35 